\title{
Pro-Neuregulin-1, Membrane-Bound Isoform
}

National Cancer Institute

\section{Source}

National Cancer Institute. Pro-Neuregulin-1, Membrane-Bound Isoform. NCI Thesaurus.

Code C118414.

Pro-neuregulin-1, membrane-bound isoform (640 aa, $70 \mathrm{kDa}$ ) is encoded by the human NRG1 gene. This protein plays a role in tyrosine kinase receptor-mediated signal transduction. 